\title{
Research on Perfecting the Rural Social Endowment Insurance System in Yangtze River Delta
}

\author{
Shufen Zhou ${ }^{1}$, Lin Han ${ }^{1}$, Hong Wang ${ }^{1} \&$ Keying $\mathrm{Bi}^{1}$ \\ ${ }^{1}$ College of Social Sciences, Shanghai University of Engineering Science, Shanghai, China \\ Correspondence: Shufen Zhou, College of Social Sciences, Shanghai University of Engineering Science, No.333, \\ Longteng Road, Songjiang District, Shanghai, China. E-mail: qietingfengyin0608@163.com
}

Received: October 23, 2014

Accepted: November 12, 2014

Online Published: November 16, 2014

doi:10.5430/ijba.v5n6p65

URL: http://dx.doi.org/10.5430/ijba.v5n6p65

This work was supported by Shanghai universities young teacher training scheme special fund (No.ZZGJD12095) and (No.ZZGJD12014) and (N0. ZZGJD12090)and China Pu Dong Cadre College (No. celap2010-YBA-06) and Shanghai dawn track project (No.10GG22)

\begin{abstract}
Objectives: This paper analysis and summary rural endowment insurance and the typical model of the Yangtze River Delta region, from the cover, government subsidies and the level of treatment and other aspects rural pension insurance of the Yangtze River Delta region in China and the existing problems in the implementation.

Methods: Construct the Yangtze River Delta new rural endowment insurance system based on urban-rural integration; calculate through the establishment of new agricultural insurance system balance model, analysis the balance of new plan.

Results: The new rural endowment insurance system designed in this paper cover the allied farmers, land expropriated farmers and urban residents and other free occupation. It implements the work method of the government and the insured voluntary combination, and takes the mode of" individual account pension + basic pension +society as a whole".

Discussion: Improve the funding model and fund management of the Yangtze River Delta new rural endowment insurance system. Straighten the management services of the Yangtze River Delta region rural endowment insurance system.
\end{abstract}

Keywords: rural social endowment insurance system, the Yangtze River Delta region, the integration of urban and rural endowment insurance

\section{The Rural Social Endowment Insurance System of the Yangtze River Delta Region}

Following the State Council issued the" State Council guidance on the development of the rural social endowment insurance" on September 4, 2009, the Yangtze River Delta region also introduced the corresponding new rural social endowment insurance system. On December 29, 2009, Jiangsu Province issued a" implementation method of Jiangsu province new rural social endowment insurance system," On November 10, 2010, Shanghai introduced "The implementation views of Shanghai Municipal People's government to carry out State Council guidance on the development of the rural social endowment insurance". Zhejiang province brought farmer residents into the urban and rural residents' social endowment insurance and promulgated "the implementation of views of Zhejiang Provincial People's Government on the establishment of urban and rural residents' social endowment insurance system "on January 1, 2010.Searching and collecting a large number of policy documents, the author found that there are similarities and differences among the new rural social endowment insurance policies of the Jiangsu, Zhejiang and Shanghai.

\subsection{Coverage of New Rural Social Endowment Insurance System}

The coverage of new rural social endowment insurance system in the two provinces and one city is very similar, mainly forrural residents in the province or the city who reached the age of 16 years (excluding students), did not participate in the basic endowment insurance. Because the Shanghai city" urban endowment insurance "," rural 
endowment insurance"," small town social insurance" coexist," new rural endowment insurance" does not include the rural residents who participate in the small town social insurance. Zhejiang province urban and rural resident endowment insurance system coverage is also basically the rural residents.

\subsection{The Payment and Subsidy Standards of New Rural Endowment Insurance System}

The new endowment insurance individual payment standards of Shanghai, Jiangsu and Zhejiang are different. Shanghai payment standard is $500 \sim 1300$ (RMB / year), 5 grades; Jiangsu payment standard is $100 \sim 600$ (RMB / year), 6 grades; and the Zhejiang payment standard is $100 \sim 500$ (RMB / year), 5 grades. In addition, the payment standards of two provincial jurisdictions are also different, as shown in the Table 1. But the payment standards in two provinces and one city are overlap. In view of the government subsidies of the new endowment insurance payment, due to economic development differences, the gap of the two provinces and one city is larger.

Table 1. Two provinces and one city new rural endowment insurance policy comparison

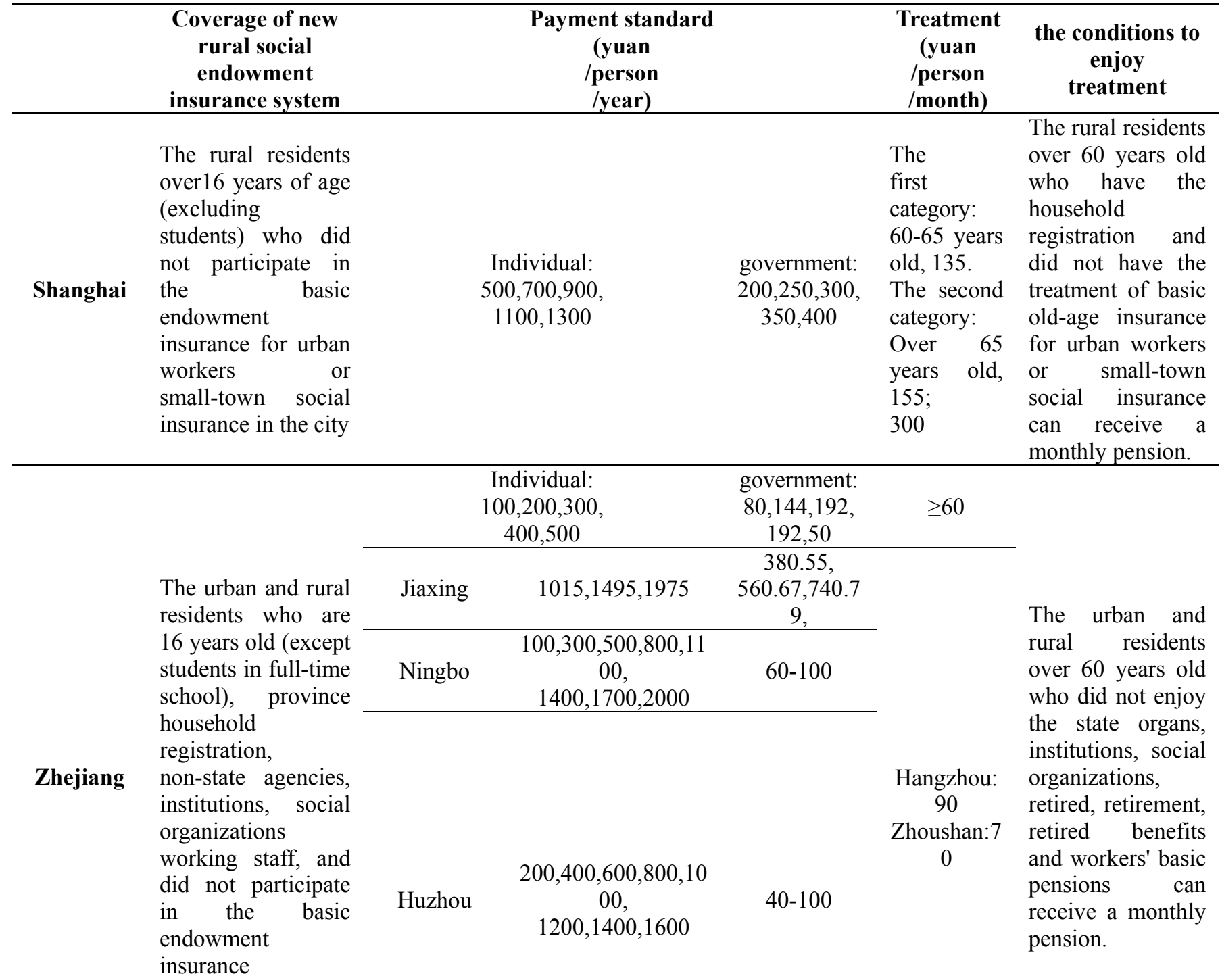

\begin{tabular}{|c|c|c|c|c|c|c|}
\hline \multirow[t]{2}{*}{ Jiangsu } & \multirow{2}{*}{$\begin{array}{l}\text { The rural residents } \\
\text { over16 years of age } \\
\text { (excluding } \\
\text { students) who did }\end{array}$} & \multicolumn{2}{|c|}{$\begin{array}{c}\text { Individual: } \\
\text { 100,200,300, } \\
400,500,600\end{array}$} & $\begin{array}{c}\text { government: } \\
30-50\end{array}$ & $\geq 60$ & \multirow[t]{2}{*}{$\begin{array}{l}\text { The rural residents } \\
\text { over } 60 \text { years old } \\
\text { who have the } \\
\text { province }\end{array}$} \\
\hline & & Nanjing & 445 (2011, for & 445 & Changzhou: & \\
\hline
\end{tabular}




\begin{tabular}{|c|c|c|c|c|c|}
\hline \multirow{5}{*}{$\begin{array}{l}\text { not participate in } \\
\text { the basic } \\
\text { endowment } \\
\text { insurance for urban } \\
\text { workers and have } \\
\text { the province } \\
\text { household } \\
\text { registration }\end{array}$} & \multicolumn{3}{|c|}{ example) } & \multirow{5}{*}{$\begin{array}{l}168 \\
\text { Wuxi:200 } \\
\text { Suzhou:100 } \\
\text { Taizhou:60- } \\
100\end{array}$} & \multirow{5}{*}{$\begin{array}{l}\text { household } \\
\text { registration and } \\
\text { did not enjoy the } \\
\text { basic old-age } \\
\text { insurance benefits } \\
\text { for urban workers, } \\
\text { in line with } \\
\text { pensioners } \\
\text { conditions, can } \\
\text { receive a monthly } \\
\text { pension. }\end{array}$} \\
\hline & Changzhou & 600 & 50 & & \\
\hline & Zhenjiang & $574,861,1723$ & & & \\
\hline & Wuxi & $\begin{array}{l}100,300,500,700,90 \\
0,1100\end{array}$ & $50-150$ & & \\
\hline & Nantong & $\begin{array}{l}\geq 991(2011, \text { for } \\
\text { example })\end{array}$ & 198.3 & & \\
\hline
\end{tabular}

The government subsidies of two provinces and one city are slightly different. In Shanghai, the corresponding premium subsidy standard is $200 \sim 400$ yuan per person per year; the subsidy standard Jiangsu local government to the insured person is $30 \sim 50$ yuan per person per year; in Zhejiang, six stalls area were given $80 \%, 72 \%, 64 \%, 48 \%$, $20 \%$ and $10 \%$ subsidy by the provincial finance, which is $50 \sim 192$ yuan. The subsidy standards of some economically developed urban are slightly higher, such as the city of Nanjing is 445 yuan, Jiaxing city subsidy standard is up to 740.79 yuan.

\subsection{The New Rural Endowment Insurance Treatment Level}

The new rural endowment insurance treatment structure and level of Jiangsu, Zhejiang and Shanghai are not the same. Jiangsu and Shanghai pension include basic pension and the pension in personal accounts, be paid for life; and Zhejiang, in addition to the first two, the endowment treatment also includes the pension calculated by payment period according to the" long pay more" principle, segmented calculation in accordance with the payment period.

The payment is different, so that the level of treatment showed a significant difference. Among them, Shanghai's average treatment is highest, while Zhejiang's average treatment is lowest.

\subsection{The Conditions to Enjoy New Rural Endowment Insurance Treatment}

The pension treatment conditions in Jiangsu, Zhejiang and Shanghai are very similar. According to the new rural endowment insurance policy, at least 60 years of age, the rural household people who did not enjoy town worker basic endowment insurance treatment can receive a monthly pension; the elderly, the rural household people over 60 years of age do not pay, can receive a monthly basic pension; under the age of 60 , they should be annual payment, but also allows to repay, when accumulated to pay the full local minimum payment standard, they can receive the monthly pension.

Through the comparison, the rural pension insurance system framework of Jiangsu, Zhejiang and Shanghai is closer, and there are similarities in some policy content. As shown in Table 1.

\section{Construction and Feasibility Analysis of the Yangtze River Delta New Rural Endowment Insurance System Based on Urban-Rural Integration}

The new rural endowment insurance system designed in this paper cover the allied farmers, land expropriated farmers and urban residents and other free occupation. It implements the work method of the government and the insured voluntary combination, and takes the mode of" individual account pension + basic pension +society as a whole".

2.1 The Frame of the Yangtze River Delta New Rural Endowment Insurance System Based on Urban-Rural Integration

2.1.1 Raising Funds Model of the Yangtze River Delta Region New Rural Endowment Insurance System

(1) Individual Payment

This paper proposed to take rural per capita net income as the paying base and implements the proportion tariff system. Take last year's rural per capita net income as the paying base, the pay grades of delta area are converted into their personal contribution rate. The base pay of Shanghai City, Jiangsu province and Zhejiang Province in 2010 respectively is their rural per capita net income in 2009, 12324 yuan, 8004yuan and 10007 yuan. As a cardinal number, then conversion, personal contribution rate shown in the Table 2. 
Table 2. Individual capture to expend scale of new type of rural endowment insurance in two provinces and one city

\begin{tabular}{ccccccccc}
\hline & \multicolumn{2}{c}{ Shanghai city } & \multicolumn{4}{c}{ Jiangsu province } & \multicolumn{2}{c}{ Zhejiang province } \\
\hline $\begin{array}{c}\text { Base } \\
\text { pay }\end{array}$ & $\begin{array}{c}\text { pay } \\
\text { grades }\end{array}$ & $\begin{array}{c}\text { individual payment } \\
\text { ratio }\end{array}$ & $\begin{array}{c}\text { Base } \\
\text { pay }\end{array}$ & $\begin{array}{c}\text { pay } \\
\text { grades }\end{array}$ & $\begin{array}{c}\text { individual payment } \\
\text { ratio }\end{array}$ & $\begin{array}{c}\text { Base } \\
\text { pay }\end{array}$ & $\begin{array}{c}\text { pay } \\
\text { grades }\end{array}$ & $\begin{array}{c}\text { individual payment } \\
\text { ratio }\end{array}$ \\
\hline 12324 & 500 & $4.06 \%$ & 8004 & 100 & $1.25 \%$ & 10007 & 100 & $1.00 \%$ \\
12324 & 700 & $5.68 \%$ & 8004 & 200 & $2.50 \%$ & 10007 & 200 & $2.00 \%$ \\
12324 & 900 & $7.30 \%$ & 8004 & 300 & $3.75 \%$ & 10007 & 300 & $3.00 \%$ \\
12324 & 1100 & $8.93 \%$ & 8004 & 400 & $5.00 \%$ & 10007 & 400 & $4.00 \%$ \\
12324 & 1300 & $10.55 \%$ & 8004 & 500 & $6.25 \%$ & 10007 & 500 & $5.00 \%$ \\
& & 8004 & 600 & $7.50 \%$ & & & \\
\hline
\end{tabular}

According to the conclusion of new rural endowment insurance actuarial, current payment ratio is low, this paper will propose the two provinces and one city to take the pay grades be $3 \%, 5 \%, 7 \%, 9 \%, 11 \%, 13 \%$ of last year's rural residents per capita income.

\section{(2) Local Government Subsidies}

Specifically, the local government subsidies mainly has two kinds, namely "s entrance" and "s export". The so-called "s entrance", namely the premium, it is financial subsidy when the farmer participate in the insurance.

The proportion of The Yangtze River Delta region local government subsidies accounting for net income shown in the Table 3 is low, in order to encourage rural residents to participate actively in the new rural endowment insurance, this paper suggests that the Yangtze River Delta region local government improve the pay subsidies to $5 \%$ of the provinces (city) net income of farmers last year.

Table 3. Delta new agricultural insurance subsidy standards

Unit: yuan

\begin{tabular}{ccc}
\hline & subsidy standards & $\begin{array}{c}\text { proportion of subsidy standards for net } \\
\text { income }\end{array}$ \\
\hline Shanghai city & $200,250,300,350,400$ & $1.62 \%, 2.03 \%, 2.43 \%, 2.84 \%, 3.25 \%$ \\
Jiangsu province & $30-50$ & $0.37 \%-0.62 \%$ \\
Zhejiang province & $80,144,192,192,50$ & $0.80 \%, 1.44 \%, 1.92 \%, 0.50 \%$ \\
\hline
\end{tabular}

The so-called "s export", namely is the basic pension.

We analysis based on the data shown in the Table 4, the standards of basic pension of two provinces and one city are slightly higher than the national standards, in 2009, pension income replacement rate of Shanghai city is $13.15 \%-29.21 \%$, Jiangsu Province's is 9\%, Zhejiang province's is $7.19 \%$, basic pension subsidy standard is low. The Yangtze River Delta region government has certain financial capacity, can be appropriate to improve the standard, and at present, the new rural endowment insurance of the Yangtze River Delta region is in good condition, basic pension can be also increased continuously.

Table 4 . The two provinces and one city pension income replacement rate

\begin{tabular}{cccc}
\hline & $\begin{array}{c}\text { Pension } \\
\text { (yuan / month) }\end{array}$ & $\begin{array}{c}\text { rural per capita net income } \\
\text { (yuan / year) }\end{array}$ & $\begin{array}{c}\text { pension income } \\
\text { replacement rate }\end{array}$ \\
\hline Shanghai city & $135,155,300$ & 12324 & $13.15 \%, 15.09 \%, 29.21 \%$ \\
Jiangsu province & $\geq 60$ & 8004 & $9.00 \%$ \\
Zhejiang province & $\geq 60$ & 10007 & $7.19 \%$ \\
\hline
\end{tabular}

Basic pension is issued for all retirees who have pension eligibility; standards across the province (city) are unified. It could reflect the mutuality to tilt the impoverished area and impoverished population, reduce barriers for the pension relationship switching and the final overall. Current our country basic endowment insurance urban workers basic pension substitution rate is not less than $20 \%$, can be set to $20 \%$ of last year's each province (city) per capita net 
income of rural residents.

\subsubsection{The New Rural Endowment Insurance Payment of the Yangtze River Delta Region}

(1) Conditions of the Pension Treatment

The elderly person who is less than 60 years old, do not participate in the basic endowment insurance and have household registration in the rural areas, may be required to receive a monthly pension. When System is implemented, the elderly person who is more than 60 years old, and do not enjoy the basic endowment insurance treatment, can receive a monthly basic pension without pay. The person who is less than 15 years to the receive age, should pay annual premium, allowed to pay, the cumulative contribution can not more than 15 years; The person who is more than 15 years to the receive age should pay the annual premium, accumulative total payment can not less than 15 years.

\section{(2) Pension Payment Method}

The pension standard of the Yangtze River Delta region is $15 \%$ of last year's each province (city) per capita net income of rural residents. Individual account annuities issuing standard of the month is individual account stores divided by 139(the same as the present basic endowment insurance individual account pension coefficient). If the insured person is dead, the individual account fund, in addition to government subsidies, can be inherited in accordance with the law; government subsidies are paid for the insured person's pension.

\subsection{Feasibility Analysis of the Yangtze River Delta New Rural Endowment Insurance System Based On Urban-Rural} Integration

System feasibility is mainly reflected in whether the new rural endowment insurance payments are balanced. This paper assumes that the full implementation of this new rural endowment insurance in 2009, government fiscal expenditures manifested in basic pension provision and payment of subsidies. Basic pension provision, pay the basic pension to the old men who are 60 and more than 60 years old according to $20 \%$ of last year's net income of farmer average per capita; payment subsidies, pay subsidies to the old men who are 16-59 years old according to 5\% of last year's net income of farmer average per capita, the sum is the financial subsidies. The government's new rural endowment insurance income is mainly reflected in the Yangtze River Delta area farmer payment, according to the premium grade determined in this paper, $16-59$ years old rural residents can pay according to 3\%, 5\%, 7\%, 9\%, 11\%, $13 \%$ of last year's per capita net income of farmers. According to different payment, we calculated total farmers payment (government revenue of new rural endowment insurance) in Yangtze River Delta region. Compared the new rural endowment insurance revenue and expenditure, we analysis the feasibility of the new rural endowment insurance.

\subsubsection{The Construction of New Rural Endowment Insurance Fund Balance Model}

The new rural endowment insurance fund balance equal to the new rural endowment insurance income minus the new rural endowment insurance expenditure, the Yangtze River Delta region new rural endowment insurance fund balance model as below:

Shanghai city:

$$
\begin{aligned}
& C_{1}=\sum(16-59 \text { years old rural population })_{t, \text { Shanghai city }} \times \lambda_{a} \times Y_{t-1} \\
& -\sum(16-59 \text { years old rural population })_{t, \text { Shanghai city }} \times 5 \% \times Y_{t-1} \\
& -\sum(60 \text { and above } 60 \text { years old rural population })_{t, \text { Shanghai city }} \times 20 \% \times Y_{t-1}
\end{aligned}
$$

Jiangsu province:

Zhejiang province:

$$
\begin{aligned}
& C_{2}=\sum(16-59 \text { years old rural population })_{t, \text { Jiangsu province }} \times \lambda_{a} \times Y_{t-1} \\
& -\sum(16-59 \text { years old rural population })_{t, \text { Jiangsu province }} \times 5 \% \times Y_{t-1} \\
& -\sum(60 \text { and above } 60 \text { years old rural population })_{t, \text { Jiangsu province }} \times 20 \% \times Y_{t-1}
\end{aligned}
$$

$$
\begin{aligned}
& C_{3}=\sum(16-59 \text { years old rural population })_{t, \text { Zhejiang province }} \times \lambda_{a} \times Y_{t-1} \\
& -\sum(16-59 \text { years old rural population })_{t, \text { Zhejiang province }} \times 5 \% \times Y_{t-1} \\
& -\sum(60 \text { and above } 60 \text { years old rural population })_{t, \text { Zhejiang province }} \times 20 \% \times Y_{t-1}
\end{aligned}
$$


In the above type, $\mathrm{t}$ means the year of $\mathrm{t}, \lambda_{a}$ represents different payment proportions, $Y_{t-1}$ means last year's rural per capita net income.

2.2.2 Calculate and Analysis Based on the Existing Data

According to the related data in 2009, we simulate and calculate payment amount of the Yangtze River Delta area rural residents and government income of the new rural endowment insurance, then; we will simulation value on new rural endowment insurance fund balance in 2009.

Shown in Table 5, because the government allowance amount is relative to determine, under different payment amount, the circumstances are different, the new agricultural insurance fund balance of the two provinces and one city are different. There is little float in Shanghai city's new agricultural insurance fund balance, between-1.096 billion to 1.632 billion. It means thatwhen all insured persons select3\% payment proportion, the new agricultural insurance expenditure is 1.096 billion than income. When the insured select $13 \%$ payment proportion, the new agricultural guaranteed income is 1.632 billion than spending, overall, Shanghai agricultural insurance payments are balance. Jiangsu province and Zhejiang province fund balance float is bigger, when their insured persons both select $3 \%$ payment proportion, Jiangsu province and Zhejiang province fund balance are respectively -13.337 billion and -15.986 billion, when their insured persons both select 13\% payment proportion Jiangsu province and Zhejiang province fund balances are respectively 21.857 billion and 30.185 billion. If the subsidy standard is unchanged, in order to maintain the balance of two provinces, proposal two provinces select $9 \%$ and $11 \%$ pay grades. But considering the two province finance income and farmer average per capita income, farmers selected low probability, and then consider to increase government subsidies.

Table 5. New rural endowment insurance fund balance simulation and calculation results of Yangtze River Delta in 2009

\begin{tabular}{|c|c|c|c|}
\hline & Shanghai city & Jiangsu province & Zhejiang province \\
\hline \multicolumn{4}{|c|}{$\begin{array}{l}\text { The payment amount (according to the different proportion) } \\
\text { (100 million yuan) }\end{array}$} \\
\hline $3 \%$ & 3.77 & 50.44 & 69.66 \\
\hline $5 \%$ & 6.28 & 84.06 & 116.10 \\
\hline $7 \%$ & 8.79 & 117.69 & 162.54 \\
\hline $9 \%$ & 11.30 & 151.32 & 208.97 \\
\hline $11 \%$ & 13.81 & 184.94 & 255.41 \\
\hline $13 \%$ & 16.32 & 218.57 & 301.85 \\
\hline $\begin{array}{l}\text { Government allowance amount } \\
\text { (100 million yuan) }\end{array}$ & 14.72 & 183.81 & 229.52 \\
\hline \multicolumn{4}{|c|}{$\begin{array}{l}\text { The aggregate balance (according to the different proportion of payment) } \\
\qquad(100 \text { million yuan })\end{array}$} \\
\hline $3 \%$ & -10.96 & -133.37 & -159.86 \\
\hline $5 \%$ & -8.44 & -99.74 & -113.42 \\
\hline $7 \%$ & -5.93 & -66.12 & -66.98 \\
\hline $9 \%$ & -3.42 & -32.49 & -20.54 \\
\hline $11 \%$ & -0.91 & 1.13 & 25.90 \\
\hline $13 \%$ & 16.32 & 218.57 & 301.85 \\
\hline
\end{tabular}

\section{The Countermeasures to Improve the Yangtze River Delta Region Rural Endowment Insurance System}

Due to the new rural endowment insurance system is in the initial stage, the system design is relatively rough, it needs further improvement and optimization. The construction of new rural endowment insurance system between in Yangtze River Delta region and other parts of the country are different, but the new rural endowment insurance system of different regions also has many similarities, establish the Yangtze River Delta new rural endowment insurance system based on urban-rural integration, it can provide construction to further optimize our new rural endowment insurance system. 


\subsection{Improve the funding Model of the Yangtze River Delta Region New System of Rural Endowment Insurance}

\subsubsection{Establish the Dynamic Pay Growth Mechanism}

In the view of development, the state also should timely adjust the pay grades based on the growth of rural per capita net income in the future, and it will reflect the affordable principle, and is helpful for the establishment of the linkage mechanism of insured people's payment and income growth.

Take the per capita net income of farmers as the paying base, implement the proportional rate system. Calculate people payment according to the actuarial balance principle. According to the calculation, we determine the $3 \%, 5 \%, 7 \%, 9 \%, 11 \%$ and $13 \%$ of rural residents per capita last year's income as the payment standard of the Yangtze River Delta region. Through calculating, it is suggested that Jiangsu province and Zhejiang Province select 9\% and $11 \%$, Shanghai city select the two grades of $11 \%$ and $13 \%$. In this case, the new rural endowment insurance revenue and expenditure of the two provinces and one city can be balance.

\subsubsection{Establish a Reasonable Allowance Standard}

The government subsidy on rural endowment insurance personnel include payment subsidies and pension subsidies, which is often referred to as" s entrance" and" s export". The national new rural endowment insurance system regulations, local government should give not less than30 yuan per person per year payment of subsidies to the insured farmers. Because the Yangtze River Delta region economic development level is higher, through the establishment of model and calculating, this paper propose improving payment subsidies standards of the Shanghai city and Jiangsu province to $5 \%$ of last year's the provinces ( city) net income of farmers, while the Zhejiang province fee subsidy standard is set to $3 \%$.

This paper suggests that Shanghai city and Jiangsu province pension subsidy standard be set as $20 \%$ of last year's province ( city) per capita net income of rural residents, and the pension subsidy standard in Zhejiang province is $10 \%$. In the basic pension, we suggest that the Yangtze River Delta region be best to assure the provinces (city) uniform, on one hand, impoverished economic support to the disadvantaged farmers of regions in the policy, reflecting social mutual aid, on the other hand, take the lead in realizing rural endowment relations shift connection in the Yangtze River Delta region, and then extended to the whole country.

3.1.3 Encourage the Development of Collective Economy in Order to Realize the Endowment Insurance Gold Much Channel to Raise Money

The Yangtze River Delta region government should use existing advantage, expand collective economy energetically, guide and encourage development of local town and township enterprises, promote the collective economy to take subsidies to new rural endowment insurance system, government corresponding give some preferential policies to such enterprise. For example, the government can formulate policy, order pension insurance be implemented as pre-tax expenses, make collective economy exert the maximum effect.

\subsection{Improving New Rural Endowment Insurance Fund Management of the Yangtze River Delta Region}

\subsubsection{Improve the New Rural Endowment Insurance Level of the Yangtze River Delta Region}

In the view of the fund management, the article suggested that the new rural endowment insurance of the Yangtze River Delta region achieve the provincial level plan. Plan the insured personnel management, endowment insurance premium collection and pension, individual account management and other aspects of the work. On the popularization of insurance, mobilization and advisory functions were handed over by the County Township, a hierarchical efficiency in management, can effectively improve the participation rate, faster system to achieve full coverage. At the same time, strengthen fund management, guarantee the system be linked. This paper suggested that the Yangtze River Delta region can employ senior professionals to unified management of rural endowment insurance funds operation, in order to ensure its security and stability, and realize the value preserving and appreciation of the fund.

\subsubsection{Implement the New Rural Endowment Insurance Funds to Preserve and Increase the Value}

Value of the fund preserving and increasing is the important conditions to ensure that the Yangtze River Delta region new rural endowment insurance system be implemented. This paper suggests two lines of revenue and expenditure be set in the fund management of the Yangtze River Delta region, the government set up a special mechanism to guarantee the special fund, expressly prohibited misappropriating even wasting the funds in any form; in addition, after reserving payment for a certain period, the government may entrust a professional fund management institution to investment, to ensure the appreciation keeping a cost of capital. In order to guarantee the money earmarked for investment, and its rationality, we should establish the proper rural endowment insurance fund supervision 
mechanism. At the same time, the government also should develop the restriction policies in the Yangtze River Delta region rural old-age insurance funds, to ensure that the new rural endowment insurance system be sustainable developed.

\subsection{Straighten the Management Services of the Yangtze River Delta Region Rural Endowment Insurance System}

3.3.1 Strengthen Network Construction of the New Rural Endowment Insurance Management Information System

The Yangtze River Delta region should seize network construction of the rural endowment insurance management information system, ceaseless aggrandizement rural endowment insurance fund management standardization. At the same time, it is necessary to improve and strengthen that the regional government agencies entrusted financial institutions to withhold individual endowment insurance, as well as to send rural endowment insurance subsidies, it can save administrative costs while this reduction in circulation of the rural endowment insurance.

In order to accelerate the integration of urban and rural development, the Yangtze River Delta region should be harmonious and unified with the city endowment insurance in rural endowment insurance management system construction as far as possible, it is convenient for them be articulated and brought into the" golden insurance project". At present, the two provinces and one city of the Yangtze River Delta region have their own independent development of rural endowment insurance information system, then, we should actively seek the opportunity to unify their systems, accelerate the integration of urban and rural and regional integration.

\subsubsection{Integrate Service Resources, Improve the Handling Efficiency}

In order to improve the handling efficiency, the Yangtze River Delta region new rural endowment insurance system implementation requires a set of relevant supporting measures to implement at the same time. The most important thing is to strengthen the organization and personnel, as far as possible to meet the actual needs of the business. The Yangtze River Delta region must update the department handling means, unified business processes, take the lead in establishing a unified system software and network construction planning in the Yangtze River Delta region, to ensure that the three system structure, service module, data interface and the index system and other aspects can be the same. In addition, unify Yangtze River Delta region new rural endowment insurance agency management model, as far as possible to achieve the unified process, in order to reduce the management cost and the difficulty, it can also

integrate services resources, improve the service carrier optimize service processes, spare no effort to facilitate and serve the masses.

\section{References}

Deng, Dasong, \& Liu, Chang-Ping. (2007). Research on the new rural social insurance system. People Press.

Li, Yingsheng. (2001). The way to explore the integration of urban and rural areas of China's social insurance system. Zhejiang Academic Journal, 5.

Mi, Hong. (2007). Rural social endowment security theories, methods and system design. Zhejiang University Press, 33.

Wang, Guojun. (2000). Convergence of Chinese urban and rural social insurance system. System Reform Research, (2).

Yang, Cuiying, \& Mi, Hong. (2007). Rural social endowment insurance: institutional arrangements and policy ideas based on the concept of limited financial responsibility. Northwest $A \&$ F University Academic Journal, (5). 